\title{
Virtual Ummah and Religious Movement Contestation: Identity and Discourse
}

\author{
M K Zuhri ${ }^{1}$, M M Jamil², M Sobirin 3 , I Taufiq ${ }^{4}$ \\ Faculty of Ushuluddin and Humanities, UIN Walisongo Semarang, Indonesia ${ }^{1,2,3,4}$ \\ \{mishbah@walisongo.ac.id ${ }^{1}$, mukhsin_jamil@walisongo.ac.id ${ }^{2}$, mohamadsobirin@walisongo.ac.id ${ }^{3}$, \\ imamtaufieq@,walisongo.ac.id $\left.{ }^{4}\right\}$
}

\begin{abstract}
The virtual ummah is a study of the object of the Ulama's behavior and the virtual ummah in using the internet as a means of spreading ideas, forming community networks and movements. This research uses a virtual ethnographic approach. The engagement of Ulama and followers in the digital world shows that new media, both in the form of online media and social media, have resulted in changes in all aspects of life, including socio-religious life. Changes that arise from the dynamics of socio-technology have three fundamental characteristics: informational, global, networking. Based on the analysis of figures and discourse content that appears in the network of Ulama and virtual Ummah, we can understand the new symptoms of the virtual Muslim community in Indonesia. Virtual Islamists are supported by puritan Muslim figures. This group activist through social media is a means to reunite the Ummah in the form of e-Ummah or virtual Ummah. Digital social platforms are expected to contribute to creating a virtual community identity that is a way for the opening of the real community of Muslim world.
\end{abstract}

Keyword: Ummah, virtual, identity, discourse

\section{Introduction}

Having billions of people online, exchanging information through social media becomes the most preferable choice to cut the high cost of circulating the info through traditional ways. Only in one click, the information will be forwarded to as many people as possible. Its ability to reach people in the fastest way, further, becomes the reason why social media is preferred to be media for speeding the spread of information. Information appears based on social media users' friends sharing information, or from where users choose to receive information from. It could be truthful and untruthful.

Whatever information is, social media will always have something to share. Looking at the enthusiasm netizens (especially young people) exhibit in social media, stakeholders, politicians, businessmen, activists even religious preachers attempt to take advantage of it, especially to exercise their influence and collect public support. While the involvement of the first four groups in social media is not new to the Indonesian digital world, the appearance of the last group (religious preachers) in online networking sites heralds a milestone in social media use.

These religious preachers have moved their religious routines online(further will be referred to as "Virtual Ulama"). They record their daily activities, experiences, thoughts/opinions online to 
influence their audiences (especially youth) to follow the path they consider it 'Islamic'. The most recent activity of self-recording opinions and experiences online is now called Vlogging. For example, Yusuf Mansur and Felix Siauw, they are among those who vlog to gain wide acceptance from digital audiences. Even though their online activities quite often invite controversies, this new way of da'wa is proven to have successfully persuaded many young people to subscribe to religion.

Considering the uniqueness of this new trend in $d a^{\prime} w a$ and the importance of discussing this issue for the study of Islam, Islamism and civil society (including the idea of nationalism), this research project attempts to discuss social media-FB, Twitter, IG, and Vlog as new digital religious mimbar for Ulama to preach for Islamic doctrines. But to narrow down the scope of the discussion, this research will talk mainly about two virtual Ulama activities related to the interplay between civic education and nationality.

This research focus on issues of nationality and religiosity has a reason; Indonesia's 200 million Muslims are not a homogenous group and differences persist in regards to Islam and the role Islam should play in both society and governance [1]. The vast majority of Indonesians identify as moderate Muslims that support a tolerant and democratic society. Yet, since 1998 with the fall of Suharto and the commencement of the Reformation period, a rise in Islamization has occurred, most notably with Islamic political organizations and violent terrorist attacks [2].

The Indonesian government is actively working with the Australian government to fight terrorism and develop a recent partnership called countering violence extremism (Carrol, 2016). In an effort to counter extremism, both governments should also look closely at digital or virtual educational contexts such as exploring how and in what ways virtual religious leaders influence the radicalization process and the development of Islamist worldviews.

Moreover, there is little research that explores how Ulama dan Ummah in digital world educates for or against radical thought and behavior, and no research that we could find that explores how Indonesian virtual Ulama educate their virtual Uummah for or against the interplay between religiosity and nationality. This research project seeks to fill this gap by exploring the role of Indonesian virtual Ulama in play in preaching doctrines that educate for or against the interplay between religiosity and nationality for virtual Ummah.

\section{Method}

Digital ethnography as an approach, of course, builds on 'pre-digital' ethnography. Ethnography, with its roots in anthropology, takes as its object of interest the very lived reality of people, of which it aims to produce detailed and situated accounts - in the words of Geertz [3], 'thick descriptions'. As such, ethnography is the approach of choice against generalization and narrow assumptions regarding the universality of digital experience in general [4], or, in terms of language use, against the kinds of sweeping statements on for instance 'the language of emails' produced in the first wave of research on technologically mediated communication. Seen from the perspective of long-term developments in the study of technologically mediated communication, research under the umbrella 'digital ethnography' has deepened our understanding of locally specific digital practices. Using the internet, and using language and other semiotic means in doing so, are locally situated experiences and entail locally specific practices, platforms, and serializations, and ethnography has precisely the means of capturing this, taking the task of 
understanding informants' life-worlds and their situated practices and lived local realities. To this end, ethnographic fieldwork is essentially a learning process where research is guided by experience gathered in the field; it is a mode of discovery and learning [5] - as Dell Hymes [6].

Even if ethnography was reduced to techniques when it comes to studying 'the internet' or digital environments, it would be extremely difficult to outline a simple set of techniques to follow: there is no 'one size fits all' solution, not least due to the myriad of different communicative environments that digital communication encompasses. Also, ethnography as an approach, in any case, is methodologically flexible and adaptive: it does not confine itself to following specific procedures, but rather remains open to issues arising from the field. With digitalization and the attendant new types of communicative environments, debates have emerged as to how exactly study these new forms of interaction, and whether 'pre-digital' methodologies and approaches can be successfully applied in research on them. However, rather than discussing which 'offline' methodologies could be successfully applied to researching online environments and how the questions raised by the study of digital environments could be used to reflect more broadly on methodologies and their epistemological nature.

The research will be a qualitative case study that will use three data collection techniques: semi-structured individual interviews, virtual Ulama's site observations (real followers), digital ethnography, document collection, and analysis. Qualitative methods will be the best way to obtain the "lived experiences" of virtual Ulama in order to better understand what they know, how they provide scaffolding to their followers, their process they have put into place, and their value systems. Trustworthiness will be established through member checks, follow-up interviews, peer debriefing, collaborative processes, and rich data collection [7].

\section{Result and Discussion}

In this section, we will discuss the two scholars and the discourse produced by the virtual ummah regarding these two scholars. They are KH. Ahmad Musthofa Bisri and Ustaz Abdul Somad. The discourse studied is a virtual discussion of the ummah from June 1 to November 15 , 2018. The discourse is on online media and social media Twitter. The discourse was chosen based on the highest rating, hashtag, and most retweeted status. Collecting data using Astramaya's social network analysis system.

First, KH. Ahmad Mustofa Bisri often called Gus Mus. Even though he belongs to the 'traditional cleric (affiliated with Nahdlatul Ulama'), but he is active in the virtual world. Gus Mus has social media accounts on several platforms, Twitter, Instagram, and Facebook. He manages these accounts himself.

Netizens' conversations about Gus Mus from June 1 to November 15 on social media, especially Twitter and news on online news portals, showed a strong presence in the virtual world. In that range, netizens' conversations in the mass media were 858 , while those on social media had a much larger number, 54,631. The percentage of that number is conversations in mass media at $2 \%$, and conversations on social media at $98 \%$. 


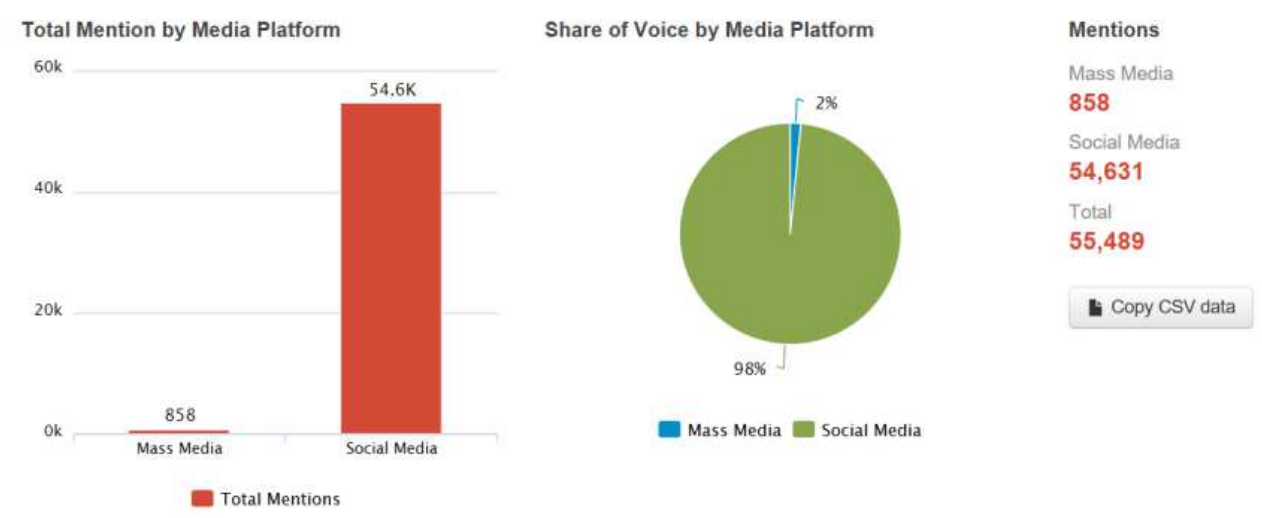

Picture 1. Gus Mus's Distribution of Mention by Media

Netizens' conversation about Gus Mus on social media shows that the conversation on Twitter has the highest number; 52,039 . This amount is equivalent to $94 \%$. The rest on social media is $6 \%: 1 \%$ on Facebook, $3 \%$ on Instagram, $1 \%$ Youtube, and $1 \%$ online news.

The conversation trend is more dominant on Twitter, so it becomes important to see in more detail how the activities of netizens in bringing up Gus Mus on Twitter. Activity on Twitter is divided into 3, namely, mention, reply, and retweet. The total daily activity about Gus Mus is Mention at 4,427 (8.49\%), replies at 8,740 (16.77\%), and retweeting at Gus Mus's status at 38,965 (74.74\%). The total number of netizens' activities was 52,132.

Meanwhile, the profile of netizens who talked about Gus Mus on Twitter is based on the number of posts dominated by netizens who only have posted a number of 1-5, with a number of 27,026. Meanwhile, netizens with the highest frequency in posting (50 and more than 50 posts) only numbered 14 netizen accounts.
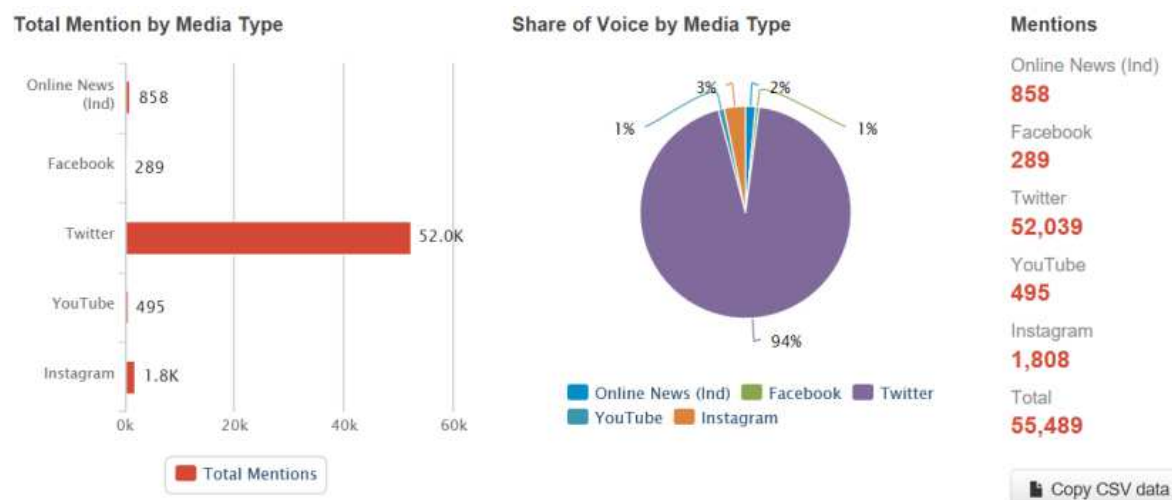

I. Copy CSV data

Picture 2. Gus Mus's Total Mention by Media Type 
On another dimension, there are netizens who have an impact on conversations about Gus Mus on social media. This account in addition to showing their relationship with Gus Mus, also shows how Gus Mus's presence on social media Twitter was welcomed and responded by netizens. Some of these accounts are@MataNajwa (impact 173, 353, 319), @sudjiwotedjo (impact 21, 009, 859), @NajwaShihab (impact 19,134,312), @kompascom (impact 13,848, 660), and @ganjarpranowo (impact 11,963,732).

There are several engaged users in your Gus Mu account. The account is actively retweeting and replying to the Gus Mus account. These accounts are Gus Mus's own accounts (7,553 3ngagements), @matanajwa (2,499 engagements), @mohmahfudmd (2,151 engagements), @islamidotco (1,344 engagements), @islamramahdotco (6,170 engagements), and several others.

The discussion graph about Gus Mus shows that the peak of the conversation occurred on August 9, 2018, with the process starting from August 8 to August 20, the highest conversations after that occurred sequentially on September 26, August 17, October 1, and October 19.

The online media conversation on 9 August 2018 contained coverage of Gus Mus's views on the election of Rais 'Am PBNU, KH. Ma'ruf Amin, to go alongside Jokowi as a vicepresidential candidate in the 2019 presidential election. On that date, there were 49 articles. Gus Mus was surprised to find out KH. Ma'ruf Amin accompanied Jokowi. The news is presented by presenting Gus Mus along with Ganjar Pranowo, Governor of Central Java. One of the news is "Ganjar Pranowo and Gus Mus Shocked to Know KH Maruf Amin Becomes Vice President Jokowi, published at http://www.tribunnews.com/, http://regional.kompas.com/, and many others. This is one of the published news excerpts:

"Sampun maos (membaca) berita Mas?"

"Dereng Gus. Lha pripun? (belum Gus, bagaimana?)"

"Lha niki kok cawapres e Pak Maruf Amin?"

"Lha pripun? Kulo kaget (lah bagaimana? saya kaget)."

"Kulo nggih kaget Gus (saya juga kaget Gus). Lah kagete pripun Gus? (lah kagetnya bagaimana Gus?)"

"Nganu, mungkin pilihane kudu niku (ya mungkin pilihannya harus itu)"

According to Ganjar, KH. Maruf Amin was considered to be very appropriate to be Jokowi's companion, he was a figure with a high level of understanding of religion.

"Jadi ketika hari ini situasi eksternal sosial kapitalisasi agama dalam politik tinggi, maka saya kira butuh tokoh-tokoh agama dengan kapasitas yang tinggi. Sehingga bangsa ini jadi baik," cetusnya."

Gus Mus was discussed on social media Twitter. The graph shows that the peak of the conversation with Gus Mus happened 3 times; on June 11-13, August 9 and November 2, 2018.

On 11-13 June 2018, a tweet from Mahfudz MD that mentioned the Gus Mus account. In his tweet, Mahfudz MD praised Gus Mus's scholarship,

“Terkadang sy ingin spt Gus Mus @gusmusgusmu, selalu sejuk dan kalem spt Abu Bakar. Tapi dlm berjuang hrs ada jg orang2 yg berani menggebrak keras spt Umar bin Khaththab. Kedua cara itu hrs ada barisan yg mewakili dlm perjuangan, terutama utk melawan koruptor2 dzolim."

In the next tweet, August 9, 2018, which occupies the top position, was discussed by netizens, from June to November. Gus Mus suggested that PBNU administrators conduct political practices wisely. 
"Para pengurus/pemimpin NU yang harus bersikap hati-hati dalam menyampaikan pernyataan-pernyataan; terutama bila berkaitan dengan politik praktis. Dan sebaiknya tak usah bicara politik praktis di kantor NU. Bukan tempatnya."

On November 2, 2018, Gus Mus asked everyone, to be wise and peaceful.

"Sekarang berhentilah membakar-bakar yang tidak enak dibakar. Termasuk membakar emosi dan bendera. Nyamankan negeri kita bersama dan marilah berjamaah mencari ridaNya"

Discourse about Gus Mus in the virtual world can be traced through the hashtag. There are several hashtags developed by netizens in framing Gus Mus. Some of these hashtags are \#MataNajwaKarenaBendera (1516 tweets), \#JanganSuriahkanIndonesia (970), \# 2019GantiPresiden President (540), and others. For example, Hashtag \#MataNajwaKarenaBendera, which is the highest number in netizens' tweets, contains their status about Gus Mus's expression on the Mata Najwa program quoted by netizens. The following excerpts from Gus Mus's statement,

"Allah memang menyuruh kita menegakkan kebenaran, tapi Lillah, bukan untuk diri kita, bukan untuk kelompok kita, bukan untuk siapa-siapa, tapi Lillah, untuk Allah saja. Ini firman Allah bukan kata saya"

The next most hashtag, \#JanganSuriahkanIndonesia, contains Gus Mus's appeal, which was quoted by netizens from various Gus Mus advice on several occasions when giving speeches, and filled the event.

"Indonesia adalah rumah kita, tempat kita lahir, tumbuh dan besar, serta mati dan dikubur. Maka, jagalah dan rawatlah."

Second, Ustaz Abdul Somad. He is often called a UAS. His name has skyrocketed in recent years, especially when he was nominated to be vice president Prabowo Subianto. That is why he is referred to as the preacher of a million followers, replacing Zaenuddin MZ as a million people. Abdul Somad has social media accounts on several platforms, namely Twitter, Instagram, and Facebook. The official accounts on behalf of Abdul Somad are managed by the admin team.

Netizens' conversations about Abdul Somad in the span of time from June 1 to November 15 on social media, especially Twitter and news on online news portals, showed a strong presence in the virtual world. In that range, netizens' conversations in the mass media were 581, while those on social media had a much larger number, 218,445. The percentage of that number is conversations in mass media at $0 \%$, and conversations on social media at $100 \%$.
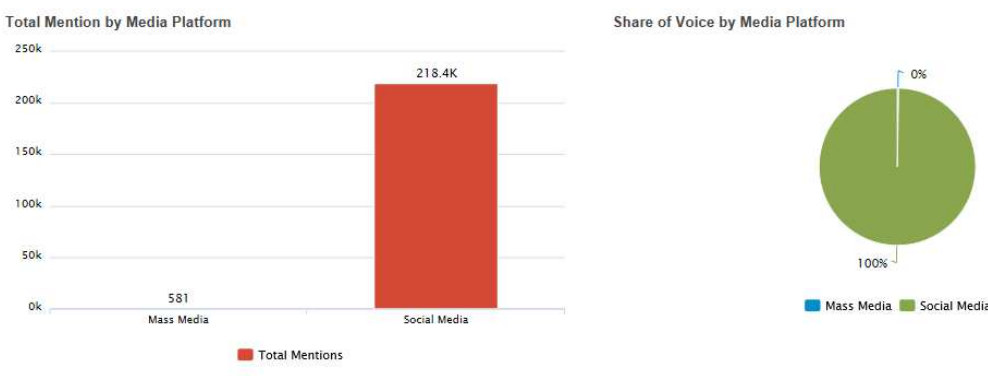

Mass Media 
Picture 3. Abdul Somad's Distribution of Mention by Media

Netizens talk about Abdul Somad on social media shows that the conversation on Twitter has the highest number; 196,054, this number is equivalent to $90 \%$. The rest of the total number of conversations on social media is 6\%: 1\% on Facebook, 3\% on Instagram, 1\% Youtube, and 1\% online news.
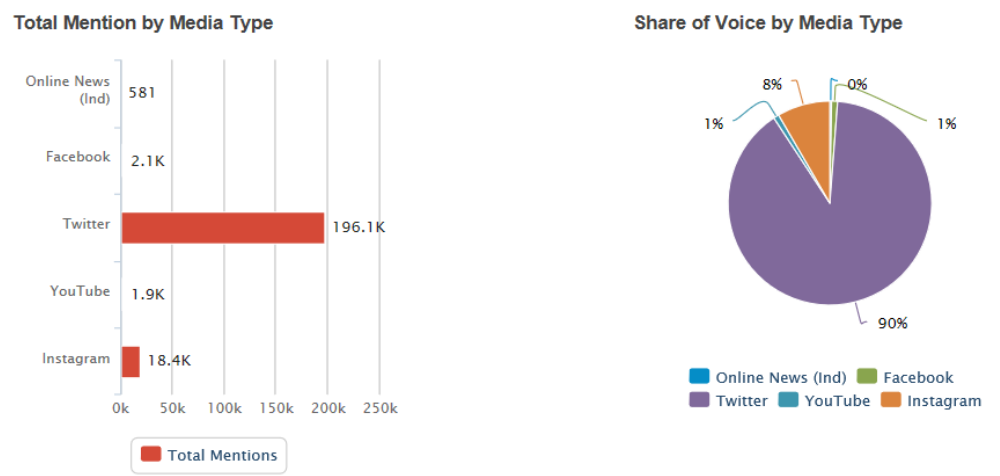

Picture 4. Abdul Somad's Total Mention by Media

Abdul Somad's conversation trends are more dominant on Twitter. Activity on Twitter is divided into 3, namely, mention, reply, and retweet. Total daily activities about Abdul Somad are Mention 27,678 (14.11\%), replies 3,767 (1.92\%), and retweet of Abdul Somad's status is 164,679 $(83.87 \%)$. The total of netizens' activities was 196,124 .

Meanwhile, the profile of netizens who have talked about Abdul Somad on Twitter is based on the number of posts dominated by netizens who only have posted a number of 1-5, with a total of 36,632. Meanwhile, netizens with the highest frequency in posting (50 and more than 50 posts) only amounted to 457 netizen accounts.

There are netizens who have an impact on Abdul Somad's conversation on social media. This account in addition to showing their relationship with Abdul Somad, also shows how Abdul Somad's presence on social media Twitter was welcomed and responded by netizens. Some of these accounts are@tvOneNews (impact 228,404,745), @VIVAcoid (impact 225,532,384), @detikcom (impact 747,802,550), @Metro_TV (impact 187,565,544), and @ liputan6dotcom (impact 91,539,045).

The engaged user in the Abdul Somad account means that the account with retweets and replies in the Abdul Somad and RT accounts and replays of Abdul Somad status by user/netizens which are then retweeted and re-supplied by other netizens shows the existence of different accounts with accounts that have impact on Abdul Somad's conversation on social media. These accounts are@abumusa86 (518 engagements),@adisyah_(270 engagements), @duta_kurniawan (281 engagements),@AmihHindarsih (286 engagements),@ syaqur1 (289 engagements).

Abdul Somad's talk chart in online media shows that the peak of the conversation chart occurred on November 5, 2018. The peak began with the process of ascending on November 2 and 
descending on November 10, and afterward ascending upward with the peak of conversation on November 13, 2018.

The conversations in the form of articles in online media during this vulnerable time all contained coverage of Abdul Somad's missionary activities in various regions in various moments of important days, such as his activities giving lectures in the grand tabligh in Kampar in commemoration of the Prophet's Birthday.

The conversation on online media is different from social media. Abdul Somad was discussed on Twitter social media. Data shows that the peak of the conversation occurred on 31 July 2018 with the process starting from 29 July and decreasing the graph on 10 August. The highest conversations after that take place sequentially on September 4-5, September 16.

On July 31, 2018, the conversation showed the views of netizens towards Abdul Somad who was included in the Prabowo Vice President's proposal for Ijtim 'Ulama. The contents of the tweet are very diverse, but the point is that Abdul Somad was chosen by Prabowo as his vice president in the 2019 presidential election,

"RT @FionaSoleha: Apabila SETUJU Tuan Guru Ustadz Abdul Somad Lc MA Menjadi CAWAPRESnya Pak @prabowo Sila RT \& Like agar Beliau bersedia..."

In a subsequent tweet, September 4-5, Abdul Somad arrived to give talks in Bali, Semarang, and Jepara which were rejected by several people. Here is an example of a netizen expression,

"RT Pantas UAS tak mau melapor ke Polisi, ternyata 'Playing Victim' Panitia Semarang \& Panitia di Malang bantah ada ancaman untuk Abdul Somad, mereka masih menunggu penjelasan karena pembatalan sepihak. Jadi siapa yg ancam Abdul Somad? Sudah keburu digoreng2 nih https://t.co/O1ol897eo5"

"RT Kronologi dan Klarifikasi Resmi Ustadz Abdul Somad saat Safari Dakwah di Bali...Bagian22@MbahUyok@NetizenTofa@Muslim_Bersatu1@RestyCayah https://t.co/Qc4GLda1ah"

Meanwhile, it was September 16, and there were 5 netizen talks about Abdul Somad. Talks about the protest against the anti-NRRI charges against Abdul Somad have been voiced by Hidayat Nur Wahid, a politician. Ha wrote,

"Ini kesimpulan KSAD : Ustaz Abdul Somad, cinta NKRI. Kesaksian yg tentunya tak hanya krn pernah dengar langsung ceramah UAS. Tapi krn fakta2 yg beliau dapat sbg KSAD. Bersama Rakyat TNI kuat. Bersama Rakyat\&Ustaz TNI tambah kuat. Semoga tak ada lagi fitnah!"

There are several "hashtags" developed by netizens in framing Abdul Somad. Among other things: \# 2019 Replace Presidents (12841 tweets), \# 2019 PrabowoSandi (4204), \#StopPers Execution (1699), and so on. For example, Hastag \# 2019GantiPresiden, is the highest number of votes, containing their status of Abdul Somad who was with Sandiaga Uno at a certain moment. Following is an example of the quote,

"RT Kenalkan CAWAPRES kita Sandiaga Salahudin Uno Baju Merah bersama USTADZ ABDUL SOMAD Baju Puth Krem. Mereka sedang menghadiri acara KEHORMATAN di Kerajaan RIAU. \#2019GantiPresiden \#2019PrabowoSandi https://t.co/ZK2DlMwPe3 "

Pada hastag terbanyak berikutnya, \#StopPersekusiUlama (1699), berisi tentang berbagai bentuk ungkapan kecewa dan kesal dari netizen terhadap terjadinya persekusi yang diderita oleh 
Abdul Somad sehingga membatalkan sejumlah kunjungan untuk ceramah. Diantaranya adalah berikut ini,

"RT Ustadz Abdul Somad batal memberikan tausyiahnya pada acara tablik akbar karena dipersekusi oleh kelompok yang katanya pancasilais. Padahal di sana ada aparat kepolisian yang harusnya menjaga pelaksanaan acara tablik akbar. \#StopPersekusiUlama - \#UlamaDukungSyariah."

\section{Conclution}

The exposure of the interaction between the 'ulama and the ummah confirmed the revolution in information and communication technology that has changed the face of the Islamic world, including the face of Indonesian Islam. The explosion of new media both online and social media has led to the development of the cyber Islamic environment and the Islamic information revolution. The development of the Islamic cyber environment is shown by the rise of the virtual ummah network. While the Islamic information revolution is shown by the abundance of information and Islamic data that can be accessed easily by the world community.

In contrast to this research, previous studies have been aimed at explaining how the influence or impact of the internet on Islam and Islamic countries. From these studies, scholars show that the digital revolution has transformed global Muslim networks [8], changing public space in various Muslim countries and Muslim minorities in the West (Dale F. Eickelman and Armando Salvatore, 2007, Bunt, 2007) and strengthen weak and marginalized groups such as Muslim women (Alexis Kort, 2005, Fatima Mernissi, 2005, Bernardi, Chiara, 2010).

Based on the data that has been described will answer some key questions about how the identity of the virtual community is formed. What discourses appear in the virtual network? How is a discourse in the virtual community-produced? These questions are the door to understanding the new reality of the public and the production of knowledge facilitated and sharpened by digital technology.

The involvement of the Ummah in the digital world with the overall consequences shows that new media (both new media) in the form of online media and social media has resulted in changes in all aspects of life, including religious social life. The spectrum of change that arises from the dynamics of sociotechnology stretches from life and personal relationships to life and social relations. The Network Society formed by information and communication technology forms a new religious movement that has three fundamental characteristics, namely informational, global, network.

The data in this study indicate the potential of online media and social media to encourage democratization in Muslims. The era of openness after the reformation in Indonesia has become a landscape and context in which freedom of expression in the Indonesian Muslim public sphere experienced an unprecedented explosion. Online media and social media have also created new Islamic authorities, which add to and challenge traditional religious structures and authorities. Not only that, the new authority also often becomes a challenge for the regime in power. This is shown in the revolutionary and radical potentials in networking and discourse in some scholars and virtual people. No doubt, the phenomenon of virtual clerics in Indonesia shows an important symptom regarding the impact of the global Mulsim cyber environment on Indonesian Muslims. Global connections or networks and the discourse they produce such as the Khilafah, for example, 
are a clear example of the global influence of the international Islamism movement which is developing in various parts of the world, on the virtuals in Indonesia.

The use of the internet has also opened the door for the emergence of new and creative thinking about ways to produce religious discourse, influence society, mobilize religious social and political resources quickly and have global influence. New media not only brings about fundamental changes in the social, political, economic and cultural fields, but also changes in aspects of thought, fatwas, and religious practices, and relationships that are established on the basis of religious norms. This tendency is both a challenge and a hope for [9].

Among the important changes in religious aspects mediated by the socio-technological environment in the development and shift of religious authority. This shift in religious authority took place at two levels, first, the de-authorization of the religious institutions which had a personal and institutional nature as the waning of ulama figures, religious clerics; secondly the strengthening of virtual authority as indicated by the influences of virtual cleric influences on the networks that form influencers in virtual communities.

Based on the analysis of figures and discourse content that appears in the virtual ulama network, it can be understood that there are two symptoms of the virtual Muslim community in Indonesia. First, the Islamic Muslim community is supported by puritan Muslim figures. Felix Show, Bahtiar Natsir, and the supporting communities of hashtag \# 2019GantiPresiden are groups with this Islamist tendency. The extent and spread of this community in online and social media show the proof of Bruinessen's [1], thesis on the return of conservatism in Indonesia. From hyperdigital activists from this group, social media is a means to back up people in the form of e-people, virtual ummah or Netumah. Digital social platforms are expected to contribute to creating a virtual community identity that is the way for the opening of the world's real Muslim community. This is done with efforts to build a network of Indonesian Islamist communities with other Islamist networks in various parts of the world.

This is important because theoretically building identity is a universal experience and becomes a fundamental source of meaning and social power. In addition, the formation of group identity can be a driving force in the contemporary world [10]. The phenomenon of the 212th movement in Jakarta, for example, proves the effectiveness of identity as a mobilization factor in the sociopolitical movement.

Other changes and developments are regarding and patterns of relationships between followers and religious leaders or leaders. Religious communication patterns develop in terms of ways and models. In the digital era, religious communication is not only direct, as we know it, face to face direct communication, but also is virtual and indirect (virtual indirect communication). Meanwhile, from the point of view of the religious communication model facilitated by digital media, communication does not only work actively but also takes place interactively. This is because the internet offers the implementation of more intermittent communication between users (users). Also not like traditional mass media, in online media and social media there is no clear boundary between the creator (producer) and receiver (receiver) messages in the virtual world. In this case, the internet represents a circular communication (circular model of communication) where participants can be together as senders as recipients of messages in communication. In the context of this circular communication model, the initiative for the production and dissemination of religious discourse in virtual Ulama does not only come from the Ulama itself but is also carried out by followers of virtual Ulama. 
The polarization of the virtual community proves the impact of social media on the religious behavior of individuals and communities in a cyber-environment characterized by the emergence of symptoms of conservative Islamism and progressive civil Islam. Activities on social media, which are the focus of this research in many ways, reflect the development of affiliations and group identities.

Theoretically building an identity is a universal experience and becomes a fundamental source of meaning and social power. In addition, the formation of group identity can be a driving force in the contemporary world [10]. The phenomenon of the 212th movement in Jakarta, for example, proves the effectiveness of identity as a mobilization factor in the socio-political movement.

Through this collective identity, virtual communities resist globalization, while at the same time developing Muslims (Muslim networks). Identities within the virtual ulama community show the operation of what Castells [10] operates as three main identities: First, Legitimizing identities namely identity created by dominant social institutions such as political regimes that control apparatus and followers in order to broaden the rationalization of their roles. Second, Resistance identities originating or created by those who experience devaluation and stigmatized by the logic of domination groups and Third Project identities that go beyond resistance and try to actively redefine their position in society by making changes to power relations in the existing social structure.

\section{References}

Castells, M. (1997)._The Power of Identity: The Information Age: Economy, Society, and Culture, Volume II . Oxford: Blackwell Publishers.

M. Van Bruinessen (Ed.) (2013), Contemporary Developments in Indonesian Islam: Explaining the "Conservative Turn" (pp. 233-240). ISEAS-Yusof Ishak Institute.

Burhanudin, J., \& Van Dijk, K. (Eds.). (2013). Islam in Indonesia: Contrasting Images and Interpretations. Amsterdam: Amsterdam University Press. doi:10.2307/j.ctt46mwqt

Geertz, Clifford. (1973). The interpretation of cultures : selected essays. New York :Basic Books.

Gabriella Coleman, E. (2010). Ethnographic Approaches to Digital Media. Annual Review of Anthropology. 39. 10.1146/annurev.anthro.012809.104945.

Blommaert, Jan \& Dong, Jie. (2010). Ethnographic Fieldwork: A Beginner's Guide.

Hymes, D. H. (1996). Ethnography, linguistics, narrative inequality: Toward an understanding of voice. London: Taylor \& Francis.

Creswell, J. W. (2013). Qualitative Inquiry \& Research Design: Choosing among Five Approaches (3rd ed.). Thousand Oaks, CA: SAGE.

Stefano Allievi, Jørgen S. Nielsen (2003). Muslim Networks and Transnational Communities in and Across Europe. Front Cover. BRILL.

Castells, M. (1997). The Power of Identity: The Information Age: Economy, Society, and Culture, Volume II_. Oxford: Blackwell Publishers.

Campbell, H. \& Teusner, P. (2011). Religious authority in the age of the internet. Virtual Lives: Christian Reflection (pp. 59-68). Baylor University Press. 